\title{
PENGESAHAN AKTA NOTARIS BAGI PENGHADAP YANG MENGALAMI
}

\section{CACA T FISIK}

Oleh:

\section{Ida Ayu Putu Swandewi*, Made Subawa**,} Gde Made Swardhana***

The Master's Program of Notary of the Udayana University e-mail : $\underline{\text { idaayuputu_swandewi@yahoo.com }}$

\section{$A B S T R A C T$}

The article 44 paragraph (1) of Law Number 2 of 2014 on the Amendment of the Law on the Position of Notary Public (hereinafter referred UUJN-P) provision a duty for the appearer to sign the notarial deed after having been read by the notary public, with the exception when the appearer is unable to put his or her signature then the appearer should mention the reason and it will be stated explicitly at the end part of the notarial deed. On the other hand, there is a difference in the arrangement of Article 16 paragraph (1) letter $c$ of the UUJN-P namely the existence of an obligation that the notary public must affix the letters and documents as well as the fingerprint of the appearer on the minutes of the deed. The problem that arises is what if the appearer is illiterate, having handicapped or paralyzed hand so that he or she could not put his or her signature on the notarial deed, whether he or she is required to put his or her fingerprints on the minutes of the notarial deed as a form of his/her personal authentication on the notarial deed or as a form of his/her approval, weather the fingerprint can replace a signature, whereas what is meant by the fingerprint here also raises different interpretations.

The study is a normative legal research, it is as a result of a vacuum of norm about the signing of notarial deed when the appearer have physical disabilities that he or she cannot sign a notarial deed and to perform validation on an authentic notarial deed that he/she made. In addition, there is a duty of the notary to affix the fingerprint of the appearer on the minutes of the notarial deed, whether this provision also applies to the appearer who cannot sign the notarial deed because of his/her disability. The materials used are the primary, secondary and tertiary legal materials.

The results of the study indicate that the legal arrangements for the legalization of the notarial deed for the appearer who has a physical disability, especially in his or her hands, as well as the obligation to attach fingerprints on the minutes of the notarial deed has not been expressly stipulated in the Law Number 30 of 2004 (UUJN) and the UUJN-P. In particular to Article 44 paragraph (1), (2) and Article 16 Paragraph (1) c. that stipulate the appearer who has a physical disability condition can authenticate the notary deed, on condition that, the deed is eligible and conforms to the rules in Article 1320 of the Civil Code, Article 1868 of the Civil Code of the authentic deed and the Law Number 30 of 2004 of the Law on Notary Position in conjunction with the Law Number 2 of 2014 on the Amendment of the Law on the Position of Notary Public.

Keywords: The Legalization of Notarial Deed, the Notarial Deed, the Physically Disabled Appearer.

* Mahasiswa Program Studi Kenotariatan T.A 2012/2013

**Pembimbing I

***Pembimbing II

\section{PENDAHULUAN}

\subsection{Latar Belakang}

Negara Indonesia adalah negara hukum. Hal ini berdasarkan ketentuan Pasal 1 ayat (3) Undang-Undang Dasar Negara Republik Indonesia tahun 1945, Negara hukum pada dasarnya bertujuan untuk memberikan perlindungan hukum. bagi rakyat terhadap tindakan pemerintah dilandasi dengan dua prinsip negara hukum. yaitu : Perlindungan hukum preventif dan represif. Notaris merupakan profesi hukum yang keberadaannya diatur dalam Undang-Undang Nomor 30 Tahun 2004 Tentang Jabatan Notaris yang diundangkan pada tanggal 6 
Nopember 2004 dalam Lembaran Negara Republik Indonesia Tahun 2004 Nomor 117 (UUJN) jo. Undang-Undang Republik Indonesia Nomor 2 Tahun 2014 Tentang Perubahan Atas Undang-Undang Nomor 30 Tahun 2004 Tentang Jabatan Notaris yang diundangkan pada tanggal 15 Januari 2014 Lembaran Negara Republik Indonesia Tahun 2014 Nomor 3 (UU Perubahan Atas UUJN). Notaris diberi wewenang selaku pejabat negara atau pejabat umum berdasarkan ketentuan-ketentuan dalam UUJN untuk menjalankan sebagian fungsi publik dari negara, di bidang hukum perdata khususnya di bidang hukum pembuktian. Akta autentik berdasarkan Pasal 1868 KUHPerdata adalah suatu akta yang dibuat dalam bentuk yang ditentukan oleh undang-undang, dibuat oleh atau dihadapan pegawai-pegawai umum yang berkuasa untuk itu ditempat dimana akta dibuatnya. Dalam hal ini pejabat yang dimaksud adalah Notaris, berdasarkan Pasal 1 angka (1) UUJN-P menegaskan bahwa, "Notaris adalah pejabat umum yang berwenang untuk membuat akta autentik dan kewenangan lainnya sebagaimana dimaksud dalam Undang-Undang ini”.

Berdasarkan Pasal 1 angka

UUJN-P bahwa, "Akta notaris adalah akta autentik yang dibuat oleh atau di hadapan Notaris menurut bentuk dan tata cara yang ditetapkan dalam Undang-Undang ini." Akta autentik menjadi bukti dari setiap sahnya perjanjian maupun tindakan hukum yang tercantum di dalamnya menjadikan produk hukum notaris tersebut harus mengikuti tata cara pembuatannya sebagaimana telah diatur dalam peraturan perundang-undangan yang artinya apa yang tercantum dalam akta tersebut harus dianggap benar adanya, sampai ada pihak yaitu biasanya pihak lawan harus dapat membuktikan bahwa apa yang tercantum dalam akta tersebut tidak benar. Syarat sahnya perjanjian menurut pasal 1320 KUHPerdata yaitu kesepakatan para pihak yang mengikatkan diri, kecakapan untuk membuat suatu perikatan, obyek atau hal yang tertentu, dan suatu sebab yang halal.

Salah satu syarat sahnya perjanjian yang diatur dalam Pasal 1320 KUHPerdata, yaitu Kecakapan para pihak dalam membuat suatu perjanjian. Cakap, artinya orang-orang yang membuat perjanjian harus cakap menurut hukum. Seorang yang telah dewasa atau akil balik, sehat jasmani dan rohani dianggap cakap menurut hukum, sehingga dapat membuat suatu perjanjian. Orang-orang yang dianggap tidak cakap menurut hukum ditentukan dalam Pasal 1330 KUH Perdata Orang yang secara normal mampu menyadari tindakan dan akibat dari tindakannya dalam hukum disebut dengan cakap bertindak. Keharusan adanya tanda tangan tidak lain bertujuan untuk membedakan akta yang satu dari akta yang lain atau dari akta yang dibuat orang lain, jadi fungsi tanda tangan adalah untuk memberikan ciri atau mengindividualisir suatu akta. ${ }^{1}$ Identifikasi dapat dilihat dari tanda tangan yang dibubuhkan pada akta tersebut, yang dimaksudkan dengan penandatangan dalam akta ini adalah membubuhkan nama dari si penanda tangan, sehingga membubuhkan paraf yaitu singkatan tanda tangan saja dianggap belum cukup, nama tersebut

${ }^{1}$ Jusuf Patrianto Tjahjono, diakses pada tanggal 7 Maret 2014, Arti dan kedudukan Tanda Tangan Dalam Sebuah Dokumen, http://notarissby.blogspot.com/2008/05/arti-dankedudukan-tanda-tangan-dalam.html. 
harus ditulis tangan oleh si penandatangan sendiri atas kehendaknya sendiri. ${ }^{2}$ Dalam pembuatan akta notaris para pihak hadir dihadapan notaris dan isi akta dibacakan oleh notaris. Berdasarkan ketentuan Pasal 44 UUJN-P sebagai implementasi peraturan jabatan notaris mengatur juga tentang ketentuan penandatanganan yaitu sebagai berikut :

(1) Segera setelah akta dibacakan, akta tersebut ditandatangani oleh setiap penghadap, saksi, dan Notaris, kecuali apabila ada penghadap yang tidak dapat membubuhkan tanda tangan dengan menyebutkan alasannya.

(2) Alasan sebagaimana dimaksud pada ayat (1) dinyatakan secara tegas pada akhir akta.

Dalam hal ini yang diwajibkan membubuhkan tanda tangan tidak hanya notaris, para pihak dan para saksi juga diwajibkan untuk membubuhkan tanda tangan dengan pengecualian apabila para penghadap tidak dapat membubuhkan tanda tangan maka penghadap harus menyebutkan alasan yang nantinya akan dinyatakan secara tegas dalam akta tersebut. Pembubuhan tanda tangan terdapat dalam penutup akta, dimana terdapat satu klausul yang disebutkan sebelumnya yaitu, "Setelah saya, Notaris membacakan akta ini kepada para penghadap dan para saksi, maka segera para penghadap, para saksi dan saya, notaris menandatangani akta ini"3.

Pasal 44 ayat (1) UUJN-P memberikan suatu kewajiban bagi para penghadap untuk menandatangani akta

${ }^{2}$ Sudikno Mertokusumo, 2009, $\underline{\text { Hukum }}$ Acara Perdata Indonesia, Edisi Kedelapan Liberty, Yogyakarta, hal.152.

${ }^{3}$ Komar Andasasmita, 1983, Notaris II, Sumur, Bandung, hal.150. setelah dibacakan oleh Notaris, dengan pengecualian apabila ada penghadap yang tidak dapat membubuhkan tanda tangan maka penghadap tersebut harus menyebutkan alasan yang nantinya akan dinyatakan secara tegas pada akhir akta. Selanjutnya terdapat suatu pengaturan baru didalam Undang-Undang Jabatan Notaris yaitu Pasal 16 ayat (1) huruf c UUJN-P berdasarkan ketentuan didalam pasal tersebut terdapat suatu kewajiban "notaris wajib melekatkan surat dan dokumen serta sidik jari penghadap pada minuta akta". permasalahan yang timbul kemudian yaitu terjadilah perdebatan dikalangan notaris yaitu arti kata melekatkan dengan membubuhkan menimbulkan suatu perdebatan kemudian bagaimana apabila penghadap mengalami cacat fisik seperti tidak mempunyai jari tangan, buta atau tidak bisa membaca dan menulis sehingga tidak dapat membubuhkan tanda tangannya pada akta, apakah penghadap tersebut wajib melekatkan sidik jari pada minuta akta sebagai bentuk pengidividualisiran akta sebagai bentuk dari persetujuan dirinya, Arti melekatkan dimaksud dengan sidik jari disini masih terjadi multitafsir ${ }^{4}$.

Para Notaris mengatakan bahwa substansi dari bunyi Undang-Undang itu sendiri tidak jelas dan menimbulkan multitafsir di kalangan notaris sendiri. Mulai dari tata cara melekatkan, sampai sidik jari yang dipakai tidak secara tegas-tegas disebutkan dengan jelas. Apakah pembubuhan sidik jari

${ }^{4}$ Kajian Yuridis dan Praktek Terhadap UU N0.2 Tahun 2014 Tentang Perubahan UU No.30 Tahun 2004 Tentang Jabatan Notaris Terkait Sidik Jari,Aspek Pidana Notaris Dan Perlindungan Notaris,serta Degradasi Akta,Renvoi, Nomor 11.131.XI, hal 85. 
merupakan suatu yang dapat mengantikan tanda tangan sedangkan yang dimaksud sidik jari disini juga menimbulkan penafsiran apakah sidik jari tangan kanan, kiri atau dapat sidik jari kaki. Perbuatan hukum ini menarik untuk ditinjau lebih jauh secara hukum karena terdapat kekosongan norma mengenai pengesahan akta notaris bagi penghadap yang mengalami cacat fisik. Berdasarkan hal tersebut diatas maka diangkat tesis yang berjudul "PENGESAHAN AKTA NOTARIS BAGI PENGHADAP YANG MENGALAMI CACAT FISIK”.

\subsection{Rumusan Masalah}

1. Apakah penghadap yang memiliki kondisi cacat fisik dapat melakukan otentifikasi pada suatu akta notariil ?

2. Bagaimana akibat hukum terhadap akta notariil yang dibuat apabila penghadap tidak dapat menandatangani akta dengan tangannya ?

\subsection{Landasan Teori}

\section{Teori Negara Hukum}

Plato mencetuskan gagasan mengenai negara hukum dengan menyatakan bahwa negara yang baik adalah negara yang berdasarkan pada adanya pengaturan (hukum) yang baik, yang disebut dengan istilah "nomoi". 5 Konsep negara hukum yang dianut Negara Kesatuan Republik Indonesia adalah sistem hukum Eropa

${ }^{5}$ Titik Triwulan Tutik, 2011, $\underline{\text { Kontruksi }}$ Hukum Tata Negara Indonesia Pasca Amandemen UUD 1945, Kencana Prenada Media Group, Jakarta, hal.61.
Kontinental (Rechtsstaat). Adapun ciri ciri Rechtsstaat ${ }^{6}$ adalah :

1. Adanya undang undang dasar atau konstitusi yang memuat ketentuan tertulis tentang hubungan penguasa dan rakyat.

2. Adanya pembagian kekuasaan negara.

3. Diakui serta dilindunginya hakhak rakyat.

Immanuel Kant dan Frederich Julius Stahl menyatakan konsep negara hukum Rechtsstaat memiliki 4 (empat) unsur pokok, yaitu ${ }^{7}$ :

1. Pengakuan dan perlindungan terhadap hak asasi manusia;

2. Negara didasarkan pada teori trias politika (adanya pembagian kekuasaan);

3. Legalitas (terkait dengan pemerintahan diselenggarakan berdasarkan undangundang atau dengan kata lain setiap tindakan harus berdasarkan hukum yang telah diadakan terlebih dahulu) ${ }^{8}$

4. Adanya peradilan yang bertugas menangani kasus perbuatan melanggar hukum oleh pemerintah.

Negara Indonesia adalah negara hukum. Hal ini didasarkan pada ketentuan Pasal 1 ayat (3) Undang-Undang Dasar Negara Republik Indonesia tahun 1945.

2. Asas Kepastian Hukum

Kepastian hukum secara normatif adalah ketika suatu peraturan dibuat dan diundangkan secara pasti karena mengatur secara jelas dan logis. Jelas dalam artian tidak menimbulkan keragu-raguan (multi-tafsir) dan logis dalam artian ia menjadi suatu sistem

${ }^{6}$ Ni'Matul Huda, 2005, Hukum Tata Negara Indonesia Edisi Revisi, PT. Raja Grafindo Persada, Jakarta, hal.82.

${ }^{7}$ Titik Triwulan Tutik, Loc.Cit.

${ }^{8}$ Andi Hamzah, 2008, Asas-Asas Hukum Pidana, Rinela Cipta, Jakarta, hal.26. 
norma dengan norma lain sehingga tidak berbenturan atau menimbulkan konflik norma ataupun adanya kekosongan norma. Konflik norma yang ditimbulkan dari ketidakpastian aturan dapat berbentuk kontestasi norma, reduksi norma atau distorsi norma. Demi tercapainya kepastian hukum maka masyarakat membuat perjanjian dalam lalu lintas hukum perdata salah satunya adanya kepastian hukum mengenai otentisitas penandantangan akta notariil yang dilakukan oleh penghadap yang memiliki kekurangan fisik (organ tangan) serta bagaimana kemudian akta tersebut dapat menjamin kepastian hukum para pihak, sehingga tidak menimbulkan terjadinya kekosongan norma, yang menimbulkan salah penafsiran dari masyarakat luas.

\section{Asas pacta sunt servanda}

Asas pacta sunt servanda merupakan asas bahwa suatu kontrak yang dibuat secara sah oleh para pihak mengikat para pihak tersebut secara penuh sesuai isi kontrak tersebut. ${ }^{9}$ Kedudukan para pihak dalam asas ini harus seimbang sehingga terjadi kepastian hukum, apabila tidak seimbang perjanjian ini dapat dibatalkan. Dengan adanya kepastian hukum ini tentunya juga menghindarkan terjadinya kekaburan norma dan kekosongan norma yang terjadi termasuk dalam hal penghadap yang mengalami cacat fisik tetap dapat melakukan perbuatan hukum karena perjanjian pada dasarnya adalah

${ }^{9}$ Munir Fuady, 2005, Pengantar Hukum Bisnis : Menata Bisnis Modern di Era Globalisasi, PT.Citra Aditya Bakti, Bandung, (selanjutnya disingkat Munir Fuadi I), hal. 12. kesepakatan para pihak dan kehendak para pihak sehingga tidak ada pengecualian terhadap penghadap yang memiliki kekurangan fisik untuk dapat membuat suatu perjanjian.

4. Teori Kemanfaatan (utilitarianisme theory)

Jeremi Bentham yaitu utilitarisme sebagai the greatest happiness fot the greatest number artinya kebahagiaan yang sebesar mungkin bagi jumlah yang sebesar mungkin. Aliran ini memberikan suatu norma bahwa baik buruknya suatu tindakan oleh akibat perbuatan itu sendiri. Apabila dikaitkan dengan Tugas notaris sebagai pejabat umum yang melayani masyarakat maka perbuatan yang dilakukan haruslah sesuai dengan aturan yang ada sehingga tidak menimbulkan pertentangan oleh para pihak atau kemudian terjadi sengketa hukum dan dapat digunakan sebagai acuuan dalam pengesahan akta yang dilakukan apabila penghadap mengalami cacat fisik .

5. Teori Perlindungan Hukum.

Philipus M. Hadjon menyebutkan bahwa perlindungan hukum meliputi dua hal. Perlindungan hukum preventif meliputi tindakan yang menuju kepada upaya pencegahan terjadinya sengketa sedangkan perlindungan represif maksudnya adalah perlindungan yang arahnya lebih kepada upaya untuk menyelesaikan sengketa, seperti contohnya adalah penyelesaian sengketa di pengadilan. ${ }^{10}$ Sebuah akta autentik dibuat pada dasarnya sebagai alat bukti apabila nantinya terjadi

${ }^{10}$ Budi Agus Riswandi dan Sabhi Mahmashani, 2009, Dinamika Hak kekayaan Intelektual Dalam masyarakat Kreatif, Total Media, Yogyakarta, hal.12. 
sengketa di kemudian hari, hal ini merupakan salah satu upaya perlindungan hukum preventif.

Definisi Konsep

a. Konsep Tanda Tangan

Menandatangani ( onderteken) secara etimologis yaitu memberi tanda (teken) dibawah sesuatu. Menurut Mr.C.JJ.De Joncheere tanda tangan tidak dapat berdiri sendiri didasarkan pada kata onderteken yaitu membuat tanda dibawah. Yang artinya bahwa membuat tanda tangan harus dilakukan dibawah sesuatu yang disebut adalah tulisan. Tan Thong Kie mendefinisikan tanda tangan sebagai suatu pernyataan kemauan dari si pembuat tanda tangan, bahwa ia menghendaki agar tulisan yang dibuat dalam suatu surat dalam hukum dianggap sebagai tulisannya sendiri dengan membubuhkan tanda tangannya di bawah tulisan tersebut. Tan Thong Kie menyebutkan "membubuhkan tanda tangannya" ini dapat diartikan bahwa yang dibubuhkan dalam tulisan atau akta adalah tanda dari tangan seseorang, jadi bisa berupa tanda tangan maupun cap jempol/sidik jari.

b. Konsep Disabilitas ( Penyandang Cacat)

Definisi dan klasifikasi penyandang cacat:

a. Peraturan Pemerintah Nomor 36 tahun 1980 tentang Usaha Kesejahteraan Sosial Penderita Cacat menyatakan bahwa: "Penderita cacat adalah seseorang yang menurut ilmu kedokteran dinyatakan mempunyai kelainan fisik atau mental yang oleh karenanya merupakan suatu rintangan atau hambatan baginya untuk melaksanakan kegiatan-kegiatan secara layak". Terdiri dari : cacat tubuh, cacat netra, cacat mental, cacat rungu wicara, dan cacat bekas penyandang penyakit kronis. b. Undang-Undang Nomor 4 tahun 1997 tentang Penyandang Cacat yang diundangkan pada tanggal 28 Pebruari 1997 dalam Lembaran Negara Republik Indonesia Tahun 1997 Nomor 9, Tambahan Lembaran Negara Nomor 3670 mengenai penyandang cacat menetapkan definisi penyandang cacat sebagai berikut: "Penyandang cacat adalah setiap orang yang mempunyai kelainan fisik dan/atau mental, yang dapat mengganggu atau merupakan rintangan dan hambatan baginya untuk melakukan secara selayaknya", yang terdiri dari:

1) Penyandang cacat fisik

2) Penyandang cacat mental

3) Penyandang cacat fisik dan mental.

\subsection{Tujuan Penelitian}

\subsubsection{Tujuan Umum}

Adapun tujuan umum penelitian ini untuk mengembangkan kemampuan diri dalam menyampaikan dan menuliskan pikiran dalam suatu karya ilmiah serta lebih mendalami dan memahami mengenai ilmu hukum secara umum dan hukum kenotariatan khususnya mengetahui cara Pengesahan akta notaris bagi penghadap yang mengalami cacat fisik serta Akibat hukum dari otentisitas akta notaris apabila penghadap tidak dapat menandatangani akta dengan tangannya.

\subsubsection{Tujuan Khusus}

1. Untuk mengkaji dan menganalisis pengaturan hukum mengenai pengesahan akta notaris bagi penghadap yang mengalami cacat fisik.

2. Untuk mengkaji dan menganalisis akibat hukum dari otentisitas akta notaris apabila penghadap tidak dapat menandatangani akta dengan tangannya. 


\section{METODE PENELITIAN}

2.1 Jenis penelitian

Jenis Penelitian yang digunakan dalam penelitian tesis ini adalah penelitian hukum normatif. Penelitian ini berangkat dari adanya kekosongan norma dalam Pasal 44 ayat (1) UndangUndang Nomor 2 Tahun 2014 tentang Perubahan Atas Undang-Undang Nomor 30 Tahun 2004 tentang Jabatan Notaris dikaitkan dengan Pasal 16 ayat 1 huruf c Perubahan Atas Undang-Undang Nomor 2 Tahun 2014 berkaitan dengan pengesahan akta autentik dan pembubuhan sidik jari pada minuta akta apabila penghadap mengalami cacat fisik.

\subsection{Jenis Pendekatan}

Pendekatan yang digunakan dalam penulisan ini adalah pendekatan peraturan perundang-undangan (statute approach) dan pendekatan konseptual (conceptual approach).

\subsection{Sumber Bahan Hukum}

Sumber bahan hukum yang digunakan dalam penelitian ini meliputi

1. Bahan hukum primer, yaitu bahan hukum yang mempunyai kekuatan mengikat, berupa peraturan perundang-undangan, yurisprudensi serta perjanjian internasional antara lain :

- Undang-Undang Dasar Negara Republik Indonesia Tahun 1945.

- Kitab Undang-Undang Hukum Perdata.

- Undang-Undang Republik Indonesia Nomor 30 Tahun 2004 tentang Jabatan Notaris (Lembaran Negara Republik Indonesia Tahun 2004 Nomor 117).

- Undang-Undang Republik Indonesia Nomor 4 Tahun 1997 tentang Penyandang Cacat (Lembaran Negara Republik Indonesia Tahun 1997 Nomor 9,
Tambahan Lembaran Negara Nomor 3670).

- Undang-Undang Republik Indonesia Nomor 2 Tahun 2014 tentang Perubahan Atas Undang Undang Nomor 30 Tahun 2004 tentang Jabatan Notaris (Lembaran Negara Republik Indonesia Tahun 2014 Nomor 3).

2. Bahan hukum sekunder, yaitu bahan hukum penunjang berupa teori-teori hukum dan pendapat para sarjana terkemuka. Bahan hukum sekunder dapat berupa semua publikasi tentang hukum yang bukan merupakan dokumen resmi, yaitu bahan hukum yang dapat memberikan penjelasan terhadap bahan hukum primer. Bahan hukum sekunder dalam penelitian ini terdiri atas:

- Buku-buku hukum mengenai jabatan Notaris.

- Artikel dan karya tulis ilmiah yang tertulis di internet

3. Bahan hukum tersier, yaitu bahan hukum yang dapat memberikan penjelasan terhadap bahan hukum primer maupun bahan hukum sekunder yang berupa kamus hukum, ensiklopedia, dan kamus besar bahasa indonesia.

\subsection{Teknik Pengumpulan Bahan Hukum}

Teknik pengumpulan bahan hukum dalam penelitian ini adalah dengan melakukan studi kepustakaan dan Secara khusus dilakukan dengan menggunakan sistem kartu (card system). Sistem kartu in secara khusus menggunakan kartu kutipan yang digunakan untuk mencatat hal-hal penting yang merupakan bahan hukum yang relevan dengan permasalahan yang dibahas

\subsection{Teknik Analisis Bahan Hukum}

Teknik analisis yang digunakan terhadap bahan-bahan hukum yang telah terkumpul untuk menyelesaikan permasalahan yang diangkat dalam penelitian ini adalah dilakukan dengan teknik deskriptif dan teknik interpretasi kemudian Teknik interprestasi yang dipergunakan dalam 
penelitian ini adalah interpretasi gramatikal (tata bahasa) dan interpretasi sistematis.

\section{TINJAUAN UMUM}

\subsection{Tinjauan Umum Akta Notaris}

3.1.1 Pengertian Akta Notaris dan Jenis Akta Notaris

Akta Notaris pada hakekatnya memuat kebenaran formal sesuai dengan apa yangdiberitahukan para pihak kepada Pejabat umum yaitu Notaris. Notaris berkewajiban mengkonstantir maksud dari para pihak dan membacakan kepada para pihak tentang isis dari akta tersebut. Pernyataan atau keterangan para pihak tersebut kemudian dituangkan dalam akta Notaris. ${ }^{11}$

Pengertian Akta notaris ditentukan dalam Pasal 1 angka 7 UUJN yang menyatakan bahwa : “akta notaris yang selanjutnya disebut akta adalah akta autentik yang dibuat oleh atau dihadapan notaris menurut bentuk dan tata cara yang ditetapkan dalam undang-undang”. Menurut Abdul Kohar, akta itu disebut autentik apabila akta tersebut dibuat di hadapan pejabat yang berwenang. Autentik itu artinya sah karena Notaris adalah pejabat yang berwenang membuat akta, maka akta yang dibuat di hadapan Notaris adalah akta autentik oleh karenanya akta tersebut dapat dikatakan sah. Akta autentik menurut pasal 1868 KUHPerdata adalah "Suatu akta yang di dalam bentuk yang ditentukan oleh undangundang, dibuat oleh atau dihadapan pegawaipegawai umum yang berkuasa untuk itu ditempat dimana akta dibuatnya". Habib Adjie menyebutkan bahwa pejabat umum merupakan terjemahan dari kata Openbare Ambtenaren yang

${ }^{11}$ Habib Adjie, 2008, Hukum Notariat Di Indonesia-Tafsiran Tematik Terhadap UU Nomor 30 Tahun 2004 Tentang Jabatan Notaris, Refika Aditama,Bandung,h.45 terdapat dalam Pasal 1 PJN dan Pasal 1868 KUHPerdata $^{12}$.

Bentuk dan Jenis Akta Notaris.

Akta Notaris sendiri terbagi menjadi 2 bentuk yaitu :

1. Akta yang dibuat oleh (door) notaris atau yang dinamakan akta relaas atau akta pejabat (ambtelijke akten).

2. Akta yang dibuat di hadapan (ten overstaan) notaris atau yang dinamakan akta partij (partij akten).

Akta yang dibuat dihadapan Notaris bentuknya telah ditentukan didalam Pasal 38 UUJN.

2.1.2 Kekuatan Pembuktian Akta Notaris

Akta autentik berfungsi sebagai alat bukti oleh karenanya Akta Notaris sebagai alat bukti mempunyai 3 (tiga) macam kekuatan pembuktian yaitu: ${ }^{13}$

1. Kekuatan pembuktian lahiriah atau diri (Uitwendige Bewijskracht)

Akta Notaris sebagai akta autentik dengan sendirinya mempunyai kemampuan untuk membuktikan dirinya sendiri sebagai akta autentik.

2. Kekuatan pembuktian formil (formele bewijskracht).

Kekuatan pembuktian formil artinya Akta Notaris harus memberikan kepastian bahwa apa yang dinyatakan dan tercantum dalam akta tersebut merupakan kebenaran yang merupakan uraian kehendak para pihak yang membuatnya.

3. Kekuatan pembuktian material (materiele bewijskracht).

${ }^{12}$ Ibid, hal.12.

${ }^{13}$ Sjaifurrachman dan Habib Adjie, 2011, Aspek Pertanggungjawaban Notaris Dalam Pembuatan Akta, Mandar Maju, Bandung, hal. 7. 
Kekuatan pembuktian material berarti bahwa isi dari akta itu dapat membuktikan keberadaannya sebagai hal yang benar dan mengikat terhadap pihak-pihak yang terlibat baik yang membuat atau menyuruh membuat akta tersebut sebagai bukti terhadap dirinya.

Ketiga kekuatan pembuktian diatas merupakan kesempurnaan akta notaris sebagai akta otentik. Apabila dalam persidangan dapat dibuktikan bahwa ada salah satu aspek yang tidak terpenuhi, maka akta yang bersangkutan hanya mempunyai kekuatan pembuktian sebagai akta dibawah tangan. ${ }^{14}$

\subsection{Tinjauan Umum Tanda Tangan}

\subsubsection{Pengertian dan Sejarah Tanda} Tangan

Menurut De Joncheere bentuk dari tanda tangan sebagai berikut :

1. Tanda tangan dibuat oleh seseorang dengan cara menulisnya perlahan lahan, seolah-olah dilukiskan atau dapat juga berupa coretan.

2. Tanda tangan yang dibuat klise (misalnya tanda tangan di uang kertas)

3. Tanda tangan yang dibuat melalui bantuan orang lain

4. Tanda tangan dibuat dengan menggunakan mesin cetak, termasuk juga stempel tanda tangan. ${ }^{15}$

Di Indonesia tanda tangan yang dibuat oleh seseorang dengan cara menulis perlahan-lahan, seolah-olah dilukiskan atau berupa coretanlah yang

${ }^{14}$ Ibid

${ }^{15}$ Tan Thong Kie, 2007, Studi Notariat dan Serba-Serbi Praktek Notaris, PT. Ichtiar Baru Van Hoeve, Jakarta, hal. 475. diakui di Indonesia, Pada awalnya Indonesia menggunakan perjanjian secara lisan sendiri serupa dengan negara-negara diatas namun pada akhirnya digunakan perjanjian tertulis sebagai alat bukti yang harus ditanda tangani oleh para pihak, sedangkan bagi orang yang tidak bisa menandatangani akan membubuhkan cap jempol pada perjanjian tertulis tersebut. Karena Notaris di Indonesia tidak mengakui penandatangan akta dengan menggunakan stempel ataupun klise. Karena apabila tanda tangan yang dibuat melalui bantuan orang lain akan menyebabkan perbedaan pada tangan tangan yang dibubuhkan pada saat itu sehingga digunakan lah cara-cara lain yang diatur oleh notaris yang digunakan sebagai bentuk dari pengesahan diri seseorang

\subsubsection{Dasar Hukum dan Fungsi Tanda Tangan}

Tanda tangan berfungsi sebagai pembuktian bahwa seseorang telah memberikan persetujuan dirinya dengan cara menandatangani sesuatu, bahwa ia menyetujui tindakan yang ia lakukan baik informasi yang terkandung didalamnya sesuai dengan tujuan dari penggunaan tanda tangan ${ }^{16}$. Pengaturan tanda tangan di Indonesia diawali dengan pengaturan tanda tangan yang diatur didalam suatu Reglement of Het Notaris Ambt In Indonesia atau Peraturan Jabatan Notaris (PJN) yaitu didasarkan pada Pasal 28 ayat (3) PJN dalam pasal ini menentukan bahwa semua akta notaris harus ditanda tangani oleh masing-masing penghadap,

${ }^{16}$ Edmon Makarim, 2011, Notaris dan Tanda Tangan Elektronik, Cetakan Pertama. PT. Rajawali Grafindo Persada, Jakarta, hal.40 
segera setelah selesai pembacaan akta itu. Akta itu juga harus ditanda tangani oleh saksi intrumentair dan oleh Notaris sendiri. Kemudian berdasarkan pasal Pasal 44 ayat (1) UU Perubahan Atas UUJN memberikan suatu kewajiban bagi para penghadap untuk menandatangani akta setelah dibacakan oleh Notaris, dengan pengecualian apabila ada penghadap yang tidak dapat membubuhkan tanda tangan maka penghadap tersebut harus menyebutkan alasan yang nantinya akan dinyatakan secara tegas pada akhir akta. walaupun tanda tangan yang tercantum didalam akta notaris tidak dapat dibaca, tanda tangan tersebut tetap dianggap sah apabila tanda tangan tersebut benar dibubuhkan oleh penghadap dan berasal dari tanda tangannya sendiri sebagaimana dijelaskan oleh Notaris pada bagian akhir akta.

\section{PENGESAHAN AKTA NOTARIS APABILA PENGHADAP MENGALAMI CACAT FISIK}

4.1 Persyaratan Pengesahan Akta Notaris

Akta notaris dapat dikatakan sebagai akta otentik atau otensitas akta Notaris yaitu:

1. Akta dibuat oleh (door) atau dihadapan seorang Pejabat publik;

2. Akta dibuat dalam bentuk dan tata cara (prosedur) dan syarat yang ditentukan oleh undang-undang;

3. Pejabat Publik oleh atau dihadapan siapa akta itu dibuat,harus mempunyai wewenang untuk membuat akta itu.

Karakter yuridis akta Notaris yaitu:

1. Akta Notaris wajib dibuat dalam bentuk yang sudah ditentukan oleh undang-undang

2. Akta Notaris dibuat karena ada permintaan para pihak,dan bukan keinginan Notaris
3. Meskipun dalam akta notaris tercantum nama Notaris,tetapi dalam hal ini notaris tidak berkedudukan sebagai pihak bersamasama para pihak atau penghadap yang namanya tercantum dalam akta.

4. Mempunyai kekuatan pembuktian yang sempurna, siapapun terikat dengan akta Notaris serta tidak dapat ditafsirkan lain, selain yang tercantum dalam akta tersebut

5. Pembatalan daya ikat akta Notaris hanya dapat dilakukan atas kesepakatan para pihak yang namanya tercantum dalam akta, Jika ada yang tidak setuju maka pihak yang tidak setuju harus mengajukan permohonan ke pengadilan umum agar akta yang bersangkutan tidak mengikat lagi dengan alasan-alasan tertentu yang dapat dibuktikan.

\subsection{Otentisitas Akta Notaris Apabila Penghadap Mengalami Cacat Fisik}

Suatu akta otentik yang dalam pembuatannya dibubuhkan suatu tanda tangan pada akhir aktanya mengakibatkan akta itu menjadi sah dimata hukum dan dapat dijadikan alat bukti yang sempurna, selama dalam proses pembuatannya telah memenuhi ketentuan Pasal 1320 KUHPerdata sebagai syarat sahnya perjanjian, Pasal 1868 KUHPerdata dan Undang-Undang Nomor 2 tahun 2014 tentang Perubahan Atas Undang Undang Nomor 30 Tahun 2004 tentang Jabatan Notaris juncto Undang-Undang Nomor 30 Tahun 2004 tentang Jabatan Notaris. Akta Notaris memiliki kekuatan pembuktian yang sempurna sebagai alat bukti dimata hukum sehingga hakim tidak perlu lagi menguji keotensitasan akta tersebut, selama tidak ada pihak lain yang menyangkal isi akta tersebut. Demikian pula halnya apabila suatu tanda tangan dibubuhkan dalam suatu akta dibawah 
tangan maka akta dibawah tangan tersebut tetap sah dimata hukum dan memiliki kekuatan pembuktian sempurna, selama pihak yang menandatangani akta tersebut tidak menyangkal bahwa memang benar ia yang memiliki tanda tangan pada akta dibawah tangan tersebut.

Berdasarkan hasil wawancara dengan Notaris B.F Harry Prastawa,SH.MH Notaris berkedudukan di Kabupaten Badung (wawancara tanggal 18 Juni 2014) menjelaskan bahwa apabila penghadap tidak dapat menandatangani akta dengan tangannya maka pada bagian akhir akta dijelaskan mengenai suatu keadaan dimana penghadap tidak dapat menandatangani akta dan oleh karenanya menggunakan tanda (pengesahan) dirinya yang lain yaitu penulisan dengan menggunakan mulut atau kakinya yang dapat dibuat dengan komparisi sebagai berikut :

"Segera setelah akta ini saya, Notaris bacakan kepada para penghadap dan saksi-saksi,maka akta ini ditandatangani oleh penghadap tuan A,saksi-saksi dan saya, Notaris sedangkan penghadap Tuan B menuliskan tanda persetujuan dirinya dengan kaki/mulutnya oleh karena tidak memiliki tangan atau jari tangan ."-..--

Apabila ada penghadap yang tidak dapat membubuhkan tanda tangan maka harus menyebutkan alasannya serta dinyatakan secara tegas dalam akta,sebagaimana yang diatur didalam ketentuan Pasal 44 ayat 1 dan 2 UU Perubahan atas UUJN Suatu akta tidak akan kehilangan otensitasnya apabila para penghadap tidak membubuhkan tanda tangannya, sepanjang keadaan tersebut dijelaskan dalam akta, sehingga apabila penghadap tidak membubuhan cap jempol atau ibu jari sebagai pengganti tanda tangan dalam pembuatan akta autentik tidak akan membawa akibat hukum yang mengakibatkan akta tersebut kehilangan otensitasnya. Akta tersebut tetap sah secara hukum dan tetap memilki nilai sebagai akta autentik walaupun tidak dibubuhkan cap jempol atau sidik jari sebagai pengganti tanda tangan karena keterangan penghadap tersebutlah yang oleh notaris diadikan sebagai dasar pengesahan akta dan keterangan inilah yang diakui sebagai pengganti tanda tangan (surrogaat tanda tangan).

\section{AKIBAT HUKUM TERHADAP AKTA NOTARIS YANG DIBUAT APABILA PENGHADAP TIDAK DAPAT MENANDATANGANI AKTA DENGAN TANGANNYA}

4.2 Pengaturan Pembubuhan Sidik Jari Terhadap Akta Notaris Apabila Penghadap Mengalami Cacat Fisik

Undang-Undang Nomor 2 Tahun 2014 sebagai Perubahan Atas Undang-Undang Nomor 30 Tahun 2014 tentang Jabatan Notaris mengatur beberapa ketentuan tambahan salah satunya adalah pengaturan tentang sidik jari yang diatur dalam Pasal 16 ayat (1) huruf c yang menentukan : Notaris wajib melekatkan surat dan dokumen serta sidik jari penghadap pada minuta akta. Dengan ketentuan pasal tersebut berarti telah adanya pengakuan terhadap sidik jari.

Sidik jari manusia digunakan untuk keperluan identifikasi karena sidik jari manusia yang satu dengan yang lainnya memiliki perbedaan. Dikalangan kepolisian Identifikasi sidik jari (daktiloskopi) sering digunakan. Dalam anatomi manusia, jempol atau ibu jari merupakan salah satu jari pada tangan. Sidik jari (fingerprint) adalah hasil reproduksi tapak jari baik yang sengaja 
diambil, dicapkan dengan tinta, maupun bekas yang ditinggalkan pada benda karena pernah tersentuh kulit telapak tangan atau kaki. Dalam bidang notariat di Indonesia sidik jari dipakai sebagai pengganti tanda tangan apabila seseorang tidak dapat membubuhkan tanda tangannya, baik karena buta huruf maupun karena tangannya cacat atau lumpuh, hal tersebut merupakan suatu hal sering terjadi di Indonesia.apabila penghadap memiliki kekurangan fisik, kewajiban penggunaan sidik jari telah diatur dalam Pasal 16 ayat (1) huruf c UU Perubahan Atas UUJN namun mengenai penghadap yang tidak dapat membubuhkan sidik jarinya belum secara tegas diatur didalam Peraturan Jabatan Notaris,Hal ini memerlukan pengaturan yang bertujuan untuk memberikan kepastian hukum bagi para pihak yang melakukan suatu perbuatan hukum yang membuat suatu alat bukti tertulis dihadapan notaris berupa akta autentik sehingga para pihak mendapat perlindungan yang sama dimata hukum dan pengaturan hukum yang jelas bukan hanya bermanfaat bagi kepentingan para pihak juga bermanfaat bagi notaris dalam menjalankan jabatannya tanpa ada pengeculian. Pada Pasal 44 ayat (1) UU Perubahan Atas UUJN terdapat keharusan apabila penghadap tidak dapat menandatangani akta dikarenakan mengalami cacat pada tangan maka menurut wawancara kepada Notaris I Made Puryatma, Notaris berkedudukan di Kota Denpasar bahwa apabila penghadap tidak dapat menandatangani akta dengan tangannya maka sesuai dengan Pasal 44 ayat (1) Perubahan Atas UUJN pada bagian akhir akta dijelaskan alasan mengapa penghadap tidak dapat menandatangani akta dengan tangannya dan oleh karena itu penghadap dapat memberikan kuasa secara lisan kepada seseorang yang ditunjuk oleh penghadap tersebut dengan persyaratan bahwa penghadap tersebut hadir dihadapan notaris dan disaksikan oleh 2 (dua) orang saksi pengenal sebagai persyaratan sahnya suatu akta notaris yang dalam komparisinya dapat dibuat sebagai berikut :

-Penghadap Tuan A telah diperkenalkan kepada saya, Notaris oleh dua orang saksi pengenal yang turut pula menghadap dihadapan saya, Notaris dan saya atas pertanyaan saya Notaris, mengaku berturut-turut bernama Tuan B lahir di...,pada tanggal...,kewarganegaraan...,pekerja an...,bertempat tinggal di .........,jalan...,pemegang Kartu Tanda Penduduk Nomor.... .........

Setiap akta yang dibacakan oleh Notaris dihadiri paling sedikit oleh 2 (dua) orang saksi, saksi pengenal dan saksi instrumenter kecuali peraturan perundang-undangan menentukan lain,dan saksi tersebut harus memenuhi syarat sebagai berikut:

a. Paling sedikit berumur 18 (delapan belas) tahun atau telah menikah;

b. Cakap melakukan perbuatan hukum;

c. Dapat membubuhkan tanda tangan dan paraf dan

d. Mengerti bahasa yang digunakan dalam akta

e. Tidak mempunyai hubungan perkawinan atau hubungan darah dalam garis lurus keatas atau ke bawah tanpa pembatasan derajat dan garis kesamping sampai dengan derajat ketiga dengan notaris atau para pihak. 
Saksi sebagaimana dimaksud diatas harus dikenal oleh Notaris atau diperkenalkan kepada Notaris atau diterangkan tentang identitas dan kewenangannya kepada Notaris oleh penghadap dimana pengenalan atau pernyataan tentang identitas dan kewenangan saksi dinyatakan secara tegas dalam akta. ${ }^{17}$

\subsection{Akibat Hukum Terhadap Akta Notaris} Apabila Penghadap Tidak Dapat Membubuhkan Sidik Jari Pada Minuta Akta

Minuta Akta adalah asli akta Notaris yang terdiri dari 2 (dua) jenis yaitu akta yang dibuat dihadapan Notaris ( akta Partij) dan akta yang dibuat oleh Notaris( akta pejabat/akta relaas). Pencantuman Sidik jari pada minut akta tidak berlaku sebagai surogaat tanda tangan yang artinya sebagai pengganti tanda tangan bagi partij akta dan tidak mempunyai fungsi apapun dalam akta pejabat, sebagaimana yang dirumuskan pada ketentuan Pasal 44 dan 46 UU Perubahan atas UUJN yaitu: Pasal 44 ayat (1) dan (2) UU Perubahan Atas UUJN sebagai berikut :

(1) Segera setelah akta dibacakan, akta tersebut ditandatangani oleh setiap penghadap, saksi, dan Notaris, kecuali apabila ada penghadap yang tidak dapat membubuhkan tanda tangan dengan menyebutkan alasannya.

(2) Alasan sebagaimana dimaksud pada ayat (1) dinyatakan secara tegas pada akhir akta.

Pada ketentuan Pasal 44 ayat (1) dan (2) UU Perubahan Atas UUJN menegaskan bahwa Akta notaris dalam bentuk akta partij harus ditandatangani oleh penghadap, dengan pengecualian terhadap penghadap yang tidak dapat membubuhkan tandatangannya, harus dilakukan dengan cara penghadap menerangkan kepada notaris sebabsebab menjadi halangan seperti penghadap mengalami buta huruf atau karena karena keadaan yang bersifat sementara atau tetap yang mengakibatkan penghadap tidak dapat membubuhkan tanda tangannya dalam akta tersebut sebagai contoh cacat atau lumpuh tangannya hasil wawancara dengan Notaris I Wayan Rasmawan yang berkedudukan di Kabupaten Badung (wawancara pada tanggal 14 Juni 2014) menyatakan bahwa "apabila penghadap tidak dapat menandatangani akta karena tidak memiliki jari tangan maka pada akhir akta dijelaskan alasan penghadap tidak dapat menandatangani akta oleh Notaris wajib dicantumkan secara tegas dalam akta dan keterangan inilah yang berlaku sebagai pengganti tanda tangan".Pasal 46 ayat 1 dan 2 UU Perubahan Atas UUJN menegaskan bahwa tanda tangan tidak diharuskan didalam dalam akta pejabat, sepanjang dipenuhi ketentuan yang didatur didalam pasal tersebut yaitu dalam hal penghadap menolak membubuhkan tanda tangannya harus dinyatakan dalam akta dengan mengemukakn alasannya atau tidak hadir pada penutupan akta, sedangkan penghadap belum menandatangani akta tersebut, hal tersebut tetap merupakan akta autentik. Sidik jari tidak memiliki fungsi apapun dalam akta pejabat.Sidik jari yang dibubuhkan pada akta bawah tangan berlaku sebagai pengganti tanda tangan, sepanjang disahkan atau dilegalisasi dihadapan notaris atau pejabat yang

${ }^{17}$ Ibid. hal 88. 
ditunjuk oleh UU yaitu Notaris, Ketua BPN, Bupati/Walikota atau Kepala Kewedanan, sebagaimana diatur dalam Pasal 1874 ayat 2 KUH Perdata.

Akta yang lahirnya sebagai akta autentik serta memenuhi syarat-syarat yang telah ditentukan oleh undangundang, maka akta itu berlaku atau dapat dianggap sebagai akta autentik, sampai terbukti sebaliknya. Berdasarkan pemaparan diatas bdan pendapat dari para sarjana bahwa dalam hal syarat objektif tidak dipenuhi, maka perjanjian tersebut batal demi hukum, sedangkan dalam syarat subjektif tidak dipenuhi, maka perjanjian itu bukanlah batal demi hukum melainkan dapat dimintakan pembatalannya. Dengan kata lain, perjanjian ini sah atau mengikat selama tidak dibatalkan oleh hakim atas permintaan pihak yang berhak meminta pembatalan itu.

Pada kekuatan pembuktian lahir akta berlaku asas acta publica probant sese ipsa, yang berarti bahwa suatu tandatangan pejabat yang tercantum dalam akta dianggap sebagai aslinya sampai ada pembuktian sebaliknya. Akibat hukum akta tidak akan kehilangan otensitasnya apabila para penghadap tidak membubuhkan tanda tangannya, sepanjang keadaan tersebut dijelaskan dalam akta,sehingga apabila penghadap tidak membubuhan cap jempol atau ibu jari sebagai pengganti tanda tangan dalam pembuatan akta autentik tidak akan membawa akibat hukum akta tersebut kehilangan otensitasnya. Akta tersebut tetap sah secara hukum dan tetap memilki nilai sebagai akta autentik walaupun tidak dibubuhkan cap jempol atau ibu jari sebagai pengganti tanda tangan. Suatu akta notaris menjadi sempurna dan sah sebagai suatu alat bukti berupa di pengadilan apabila dalam proses pembuatannya telah memenuhi beberapa persyaratan seperti telah disebutkan diatas yaitu, memenuhi syarat sahnya perjanjian Pasal 1320 KUHPerdata, memenuhi persyaratan Pasal 1868 KUHPerdata dan UndangUndang Nomor 2 Tahun 2014 tentang Perubahan atas Undang-Undang No. 30 Tahun 2004 tentang Jabatan Notaris juncto Undang-Undang No. 30 Tahun 2004 tentang Jabatan Notaris khususnya dalam penulisan ini memenuhi ketentuan Pasal 44 UU Perubahan Atas UUJN. Pada dasarnya suatu perjanjian tetap sah sebagai perjanjian selama telah memenuhi syarat sahnya perjanjian Pasal 1320 KUHPerdata, walaupun perjanjian tersebut tidak memenuhi ketentuan Pasal 1868 KUHPerdata, UUJN maupun UU Perubahan Atas UUJN khususnya tentang pembubuhan cap jempol pada akhir akta. Pembubuhan cap jempol/tanda tangan disini berakibat pada sempurnanya atau tidaknya suatu akta sebagai akta otentik, kedudukan suatu akta yang awalnya berupa akta otentik apabila tidak dibubuhkan cap jempol/tanda tangan akan berubah menjadi akta dibawah tangan. Hal ini nantinya akan berpengaruh pada fungsi akta tersebut sebagai suatu alat bukti di pengadilan.

\section{PENUTUP}

\subsection{Kesimpulan}

Berdasarkan pada pembahasan terhadap topik penulisan pada tesis ini maka dapat disimpulkan sebagai berikut:

1. Penghadap yang memiliki kondisi cacat fisik dapat melakukan otentifikasi terhadap akta notaris dengan syarat akta yang dibuat memenuhi syarat sahnya perjanjian yang tercantum didalam Pasal 1320 KUHPerdata dan Pasal 1868 KUHPerdata tentang akta autentik kemudian berdasarkan Pasal 44 ayat 1 dan 2 Undang Undang Nomor 2 Tahun 2014 tentang Perubahan atas Undang Undang Nomor 30 Tahun tentang Jabatan Notaris juncto Undang Undang Nomor 30 Tahun 
2004 tentang Jabatan Notaris pada akhir akta dijelaskan alasan penghadap tidak dapat menandatangani akta dan pada praktiknya dapat juga dilakukan dengan cara penghadap hadir dihadapan notaris kemudia nmemberikan kuasa secara lisan kepada seseorang yang ia tunjuk sebagai penerima kuasanya dan didalam akta notaris disebut juga sebagai saksi pengenal dan dapat juga dilakukan dengan tanda pengesahan dirinya yang lain yaitu mulut atau kaki walaupun tidak terdapat ketentuan mengenai hal tersebut didalam UU Perubahan Atas UUJN dengan terpenuhinya seluruh syarat-syarat dan ketentuan-ketentuan yang berlaku dalam dibuatnya akta notaris serta syarat sahnya perjanjian yang menjadi isi daripada akta tersebut, maka keberadaannya diakui sebagai akta otentik dan memiliki kekuatan pembuktian yang sempurna sebagai alat bukti.

2. Akibat hukum terhadap akta notaris yang dibuat apabila penghadap tidak dapat menandatangani akta dengan tangannya sehingga ia tidak dapat membubuhkan sidik jarinya pada minuta akta belum tegas diatur dalam Undang Undang Nomor 30 Tahun 2004 (UUJN) maupun dalam UndangUndang Nomor 2 Tahun 2014 tentang Perubahan atas Undang Undang Nomor 30 Tahun 2004 (UU Perubahan Atas UUJN dalam Pasal 44 Ayat (1) dan 2 UU Perubahan Atas UUJN Serta dalam Pasal 16 Ayat (1) huruf c, yang mengatur bahwa Notaris wajib melekatkan sidik jari penghadap pada minuta akta. Melekatkan Sidik jari pada minuta akta berarti membubuhkan sidik jari pada suatu lembar kertas terpisah yang dilekatkan pada minuta akta yang merupakan suatu kewajiban hukum yang tidak menentukan keabsahan atau otentisitas suatu akta dan hanya berfungsi menjamin kebenaran identitas penghadap serta melindungi notaris dikemudian hari apabila salah satu penghadap mengingkari tanda tangannya oleh karena itu maka akta yang dibuat tetap memiliki kekuatan hukum yang sempurna sebagai akta autentik karena bentuknya dibuat berdasarkan peraturan perundangundangan yang berlaku.

\subsection{Saran}

Adapun saran-saran yang dapat diberikan berdasarkan kesimpulan di atas terhadap pengesahan akta notaris bagi penghadap yang mengalami cacat fisik adalah sebagai berikut :

1. Pengaturan mengenai pengesahan akta yang dilakukan oleh penghadap yang mengalami cacat fisik perlu diatur didalam peraturan Jabatan Notaris terutama ketentuan mengenai kewajiban notaris dalam melekatkan sidik jari penghadap pada minuta akta dan kepastian hukum terhadap penghadap yang mengalami cacat fisik,sehingga terjadi keseragaman mengenai tindakan hukum yang harus dilakukan oleh notaris apabila ada penghadap yang mengalami kondisi fisik yang terbatas.

2. Payung hukum terhadap apa yang dimaksud sidik jari disini masih terjadi multitafsir, pengertian sidik jari terhadap Bareskrim,Pihak Imigrasi dam Lawyer juga berbeda-beda,sehingga diperlukan adanya pengaturan diadalam Peraturan Jabatan Notaris dalam pencantuman sidik jari penghadap yang bertujuan untuk melindungi notaris dan sebagai alat bukti yang sah hendaknya juga memerlukan pengaturan bagi penghadap yang mengalami cacat fisik sehingga tidak terjadi diskriminasi terhadap penghadap yang mengalami kondisi cacat fisik. 


\section{DAFTAR PUSTAKA}

\section{BUKU-BUKU}

Adjie, Habib, 2008, Hukum Notariat Di Indonesia-Tafsiran Tematik Terhadap UU Nomor 30 Tahun 2004 Tentang Jabatan Notaris, Refika Aditama,Bandung.

Andasasmita Komar, 1983, Notaris II, Sumur, Bandung.

Fuady Munir, 2005, Pengantar Hukum Bisnis : Menata Bisnis Modern di Era Globalisasi, PT.Citra Aditya Bakti, Bandung.

Hamzah Andi, 2008, Asas-Asas Hukum Pidana, Rinela Cipta, Jakarta.

Huda, Ni'Matul, 2005, Hukum Tata Negara Indonesia Edisi Revisi, PT. Raja Grafindo Persada, Jakarta.

Kie, Tan Thong, 2007, Studi Notariat Serba-Serbi Praktek Notaris, Ichtiar Baru Van Hoeve, Jakarta.

Makarim Edmon, 2011, Notaris dan Tanda Tangan Elektronik, Cetakan Pertama. PT. Rajawali Grafindo Persada, Jakarta

Tutik, Titik Triwulan, 2011, Kontruksi Hukum Tata Negara Indonesia PascaAmandemen UUD1945, Kencana Prenada Media Group, Jakarta.

Mertokusumo Sudikno, 2009, Hukum Acara Perdata Indonesia, Edisi Kedelapan Liberty, Yogyakarta.

Riswandi, Budi Agus dan Sabhi Mahmashani, 2009, Dinamika Hak kekayaan Intelektual Dalam Masyarakat Kreatif, Total Media, Yogyakarta.

Sjaifurrachman dan Habib Adjie, 2011, Aspek Pertanggungjawaban Notaris Dalam Pembuatan Akta, Mandar Maju, Bandung.

\section{Peraturan Perundang-undangan}

Undang-Undang Dasar Negara Republik Indonesia Tahun 1945

Kitab Undang-Undang Hukum Perdata

Undang-Undang Nomor 2 Tahun 2014 Tentang Perubahan Atas Undang-Undang Nomor 30 Tahun 2004 Tentang Jabatan Notaris (Lembaran Negara Republik Indonesia Tahun 2014 Nomor 3 dan Tambahan Lembaran Negara Republik Indonesia Nomor 5491).

Undang-Undang Republik Indonesia Nomor 4 Tahun 1997 tentang Penyandang Cacat (Lembaran Negara Republik Indonesia Tahun 1997 Nomor 9, Tambahan Lembaran Negara Nomor 3670).

\section{Makalah}

Kajian Yuridis dan Praktek Terhadap UU N0.2 Tahun 2014 Tentang Perubahan UU No.30 Tahun 2004 Tentang Jabatan Notaris Terkait Sidik Jari,Aspek Pidana Notaris Dan Perlindungan Notaris,serta Degradasi Akta,Renvoi, Nomor 11.131.XI

\section{Artikel}

Jusuf Patrianto Tjahjono, diakses pada tanggal 7 Maret 2014, Arti dan kedudukan Tanda Tangan Dalam Sebuah Dokumen, http://notarissby.blogspot.com/2008/05/arti-dan-kedudukan-tanda-tangandalam.html.

\section{Wawancara}

1. Notaris I Made Puryatma,SH.Mkn

2. Notaris B.F Harry Prastawa,SH

3. Notaris I Wayan Rasmawan,SH.MH 